\title{
Tadeusz Stefan Krasnodębski, Policjant konspiratorem. Szesnaście lat na muszce gestapo i bezpieki, Wyd. Arkadiusz Wingert - Przedsięwzięcie Galicja, Kraków-Międzyzdroje 2008
}

Książka Policjant konspiratorem (pięknie wydana, w twardej oprawie, z kredową wkładką ze zdjęciami) jest dokumentem dość niecodziennym, choćby z tego powodu, że stanowi pierwszą znaną mi autobiografię „granatowego” policjanta. Zacznijmy od autora: Krasnodębski urodził się w roku 1916 w Wolborzu, koło Piotrkowa Trybunalskiego. W końcu lat trzydziestych ukończył szkołę policyjną w Mostach Wielkich i na krótko przed wybuchem wojny zaczął pełnić służbę posterunkowego w Dąbrowie Tarnowskiej. Na jesieni 1939 r. zgłosił się do granatowej policji i pełnił w niej służbę aż do lata 1944 r. Równocześnie jako żołnierz podziemia pod pseudonimem „Kostek” działał w Związku Walki Zbrojnej (ZWZ), a potem w AK - rozpracowywał policję od środka, uprzedzając swoich „leśnych” przełożonych o planowanych posunięciach wroga. W lecie 1944 r. „Kostek” zdezerterował z policji i przeszedł do partyzantki. Po nadejściu Armii Czerwonej Krasnodębski dalej konspiruje, tym razem w NIE oraz w Zrzeszeniu Wolność i Niezawisość (WiN). Ukrywa się do początku lat pięćdziesiątych, kiedy to zostaje postawiony przed sądem i oskarżony o kolaborację oraz o mordowanie Żydów. Z zarzutów tych został jednak oczyszczony i powrócił do normalnego życia, oddając się pracy zawodowej oraz działalności patriotyczno-kombatanckiej. Omawianą autobiografię spisał w połowie lat osiemdziesiątych. Tak wyglądają losy autora opowiedziane w wielkim skrócie.

Osią tematyczną książki są niewątpliwie lata wojny, a konspiracja powojenna stanowi jedynie pośpiesznie załączony dodatek. Co zatem o tym okresie ma do powiedzenia zakonspirowany w policji akowiec? Od początku okupacji do dnia wyzwolenia Krasnodębski pracował, a potem walczył na terenie powiatu Dąbrowa Tarnowska. Mówiąc dokładniej - na posterunku Policji Państwowej (PP) w Otfinowie, małym miasteczku położonym na północny zachód od Tarnowa. Okolice Oftinowa i Dąbrowy to teren przeważnie rolniczy i w związku z tym książka daje pewne wyobrażenie na temat realiów wiejskich podczas okupacji. Piszę „pewne”, gdyż jej celem jest przede wszystkim podkreślenie doniosłej roli Krasnodębskiego w konspiracji i w walce $\mathrm{z}$ okupantem. Autor z powodzeniem wyprowadza w pole swoich niemieckich przełożonych, sabotuje ich zarządzenia, uprzedza osoby figurujące na listach proskrypcyjnych o grożącej im wywózce na roboty do Rzeszy, pomaga gospodarzom obchodzić nieludzkie przepisy, przymyka oczy na niekolczykowane prosięta i w ogóle daje przykład obywatelskiego zaangażowania i bezinteresownego patriotyzmu. Ukoronowaniem jego okupacyjnej kariery jest zastrzelenie znanego z okrucieństwa niemieckiego żandarma Engelberta Guzdka, którego w okolicach 
Tarnowa nazywano „Katem Powiśla”. Co prawda lokalny historyk Adam Kazimierz Musiał twierdzi, że Guzdka z całą pewnością zabił ktoś inny ${ }^{1}$, ale kto to dziś wie na pewno? Nie jest to jedyna wątpliwość dotycząca faktów: wersja autora nie zawsze pokrywa się z relacjami dużo bliższymi w czasie opisywanym wydarzeniom.

Jako przykład niech posłuży opis schwytania i zamordowania Kalma Wilka, żydowskiego policjanta z Żabna, po likwidacji getta ukrywającego się w okolicy. Krasnodębski pisze: „Wilk ukrywał się jakiś czas w Diamencie, aż spotkała go tam kiedyś narzeczona Niechciała [policjant z Otfinowa - J. G.] i opowiedziała o tym spotkaniu. Niechciał z Lewandowiczem udali się do Diamentu i zatrzymali Wilka, który chcąc się wykupić wskazał im miejsce ukrycia kosztowności, jednak na nic mu się to nie zdało, bowiem policjanci cenne rzeczy zabrali, a Żyda zastrzelili” (s. 116-117). Nieco inaczej to samo wydarzenie opisał zaraz po wojnie Albin B., jeden ze świadków zeznających w krakowskim sądzie: „Żyd Wilk szedł do mego domu i z tych pięciu chłopców jeden udał się na posterunek zameldować policji. Po chwili czasu widziałem jadących na rowerach 4-ch policjantów, a to Krasnodębski Tadeusz, Lewandowicz, Lesiński i Mądry. I przyjechali do mojego domu prosto po tego żyda i tego żyda zabrali ze sobą do posterunku i ten żyd się ich prosił żeby go puścili całkiem na wolność, to im pokaże gdzie ma schowane złoto i pieniądze. Więc policja tego żyda do Żabna poprowadziła gdzie miał schowane pieniądze i złoto i tego żyda zastrzelili i tymi pieniędzmi i złotem podzielili się wszyscy czterech policjantów”. Niby drobna różnica, ale jednak istotna...

Na podobne nieścisłości natrafiamy, czytając opis śmierci Mendla Kapelnera. Krasnodębski pisze: „Kiedyś na posterunku pojawił się Żyd, Mendel Kapelner. Przypominał strzęp człowieka. Ukrywał się od lata zeszłego roku i widać było, że jest kompletnie wyczerpany fizycznie i psychicznie. Stanął w drzwiach i poprosił »zastrzelcie mnie, bo ja już dłużej nie mogę wytrzymać«”. Autor wspomina, że sam wymigał się od egzekucji, ale jego kolega wysłuchał prośby Kapelnera i zastrzelił go przed posterunkiem. Tymczasem Franciszek S., zeznający kilka lat po wojnie, nieco inaczej zapamiętał śmierć Żyda Kapelnera: „Sołtys Władysław N. oznajmił nam, że idziemy chwytać żydka Mendla Kapelnera, że znajduje się w stodole u Migały Władysława schowany. Ja odpowiedziałem, że »łapać go nie pujdę [sic!], bo mu życia nie dałem«, lecz doszliśmy pod stodołę i tu sołtys powiedział do nas, że Władysław M. zameldował do Poster, Policji niemieckiej w Otfinowie, że w jego stodole ukrywa się żyd i policja dała mu rozkaz, aby go schwytać. I sołtys powiedział wchodźcie do stodoły i łapcie żydka i myśmy wszyscy trzech weszli do stodoły”. Inny świadek, Józef M., ujął to w paru słowach: „W 1943 roku, w maju, ludność go schwytała i oddała w ręce policji polskiej, która to zastrzeliła w/w żydka Kapelnera Mendla”. Bywały, rzecz znana, przypadki Żydów zgłaszających się do granatowych policjantów albo do niemieckich żandarmów z prośbą o szybką śmierć. Straszne

${ }^{1}$ Zob. A.K. Musiał, Krwawe upiory. Dzieje Powiatu Dąbrowa Tarnowska w okresie okupacji hitlerowskiej, Tarnów 1993. 
to, lecz prawdziwe. Wydaje się jednak, że nie należał do nich Mendel Kapelner z Siedliszowic.

Podobne wątpliwości nasuwa opis śmierci młodej Żydówki z Dąbrowy. Krasnodębski pisze: „Boruschak [żandarm niemiecki - J. G.] sprowadził sobie z Dąbrowy bardzo ładną Żydówkę, Süssównę, którą zakwaterował u Augustyńskiego, a potem w Gorzycach, u Piątkowej. Związek ten nie przetrwał długo, bo gdy dziewczyna była już w widocznej ciąży, wyprowadził ją za stodołę i zastrzelił”. Autorowi chodzi tu najpewniej o śmierć jednej z sióstr Süss - osiemnastoletniej Salomei lub też o dwa lata starszej jej siostry Heli. Z szeregu zeznań złożonych przez innych „granatowych” w latach 1946-49 wynika jednak, że to nie Boruschak dokonał mordu, lecz „granatowi” koledzy Krasnodębskiego: Szewczyk, Stachowicz oraz komendant posterunku Lewandowicz. Zachował się nawet szczegółowy opis egzekucji obu sióstr: „wówczas młody policjant Stachowicz oddał jeden strzał z karabinu do żydówek. Jedna z nich upadła na ziemię, natomiast druga żydówka poczęła krzyczeć i biec do upadniętej żydówki i ja wówczas wystrzeliłem z karabinu jeden strzał do niej; ta poczęła krzyczeć jeszcze więcej i upadła na ziemię przy tej, która poprzednio została postrzelona”.

Nie ma sensu wyliczać wszystkich nieścisłości, lecz trzeba podkreślić, że w ogóle z Żydami Krasnodębski ma pewien kłopot. Na końcu omawianej książki znajduje się specjalny obszerny szkic zatytułowany Polscy Żydzi w oczach przeciętnego Polaka (s. 389-417). Warto tu zacytować jedynie kilka fragmentów, które dość dobrze oddają ton całego wywodu autora: „Żydzi dosłownie okupowali jezdnie, chodniki, bramy, sklepy. Cała dzielnica robiła wrażenie jednego wielkiego placu targowego”. „Wobec wszechobecnej witalności i mobilności polskich Żydów, niejeden Polak był przeświadczony, iż oto stał się mniejszością we własnym kraju. Żydzi, gdy byli w większości, lub z różnych względów dominowali społecznie, czuli się pewniej, często demonstrując swoją wyższość przedstawicielom pozostałych nacji. Za to gdy byli w mniejszości ich buta natychmiast znikała, stawali się wręcz tchórzliwi, pokorni aż do uniżoności”. „Żydzi na skutek spożywania dużych ilości cebuli i czosnku roztaczali wokół siebie specyficzną woń, którą dawało się łatwo wyczuć. Przy tym nie grzeszyli oni higieną osobistą. Nawet ubrania szyte w żydowskich zakładach krawieckich woniały specyficznym »żydowskim« zapachem, zdradzającym ich pochodzenie. Znikał on dopiero po długim wietrzeniu”. „Ubogie rodziny żydowskie gnieździły się zazwyczaj w ciasnych mieszkaniach bez wygód. Najczęściej panował w nich brud. Żydzi nie okazywali specjalnego zamiłowania do czystości”. „Zamożniejsze rodziny żydowskie zatrudniały polskie służące. Często zdarzało się, że pracodawcy uwodzili je podczas służby, a gdy już zostały wykorzystane wyrzucano je, a na ich miejsce zatrudniane były nowe”. „Dzielnice żydowskie nie bez powodu uważano za oazę brudu i wylęgarnię różnych chorób zakaźnych”. Niech tu wolno mi będzie powstrzymać marsz podobnych cytatów, których - zapewniam w tej części książki jest mnóstwo.

Krasnodębski w swoich poglądach nie jest odosobniony. Podobne antysemickie bzdury można wyczytać w dowolnym hitlerowskim wydawnictwie, w prasie gadzi- 
nowej bądź też obejrzeć w szeroko kolportowanym podczas wojny filmie $\dot{Z} y d z i$, wszy, tyfus. Ciekawe tylko, że tego rodzaju idiotyzmy ukazują się drukiem w Polsce Anno Domini 2008. Wyłania się wobec tego pytanie: czy przy takich zastrzeżeniach w ogóle warto tę książkę wspominać lub czytać? Sądzę, że tak, ale tylko z jednego powodu. Czytając Krasnodębskiego „między wierszami”, możemy lepiej zrozumieć mechanizmy terroru narastającego w okupowanej Polsce. Terroru, którego ważnym narzędziem byli nie tyle dość rzadko widywani na wsiach niemieccy żandarmi, ile właśnie granatowi policjanci, wysługujący się swoim niemieckim mocodawcom oraz „pracujący” na własną rękę, rabując i męcząc lokalną ludność oraz przyczyniając się walnie do wymordowania żydowskich niedobitków.

Jan Grabowski 